\title{
Consumers' Preferences of Winter Tourist Packages in Romania: A Quantitative Case Study
}

\author{
Ioan Bogdan Bacos ${ }^{\star}$, Manuela Rozalia Gabor ${ }^{\star \star}$
}

\begin{tabular}{l}
\hline \multicolumn{1}{c}{ A R T I C L E I N F O } \\
\hline Article history: \\
Accepted December 2020 \\
Available online December 2020 \\
\hline JEL Classification \\
L83, Z32, Z39 \\
Keywords: \\
Winter tourism, Winter sports \\
tourism, Consumer preferences, \\
Case study, Romania
\end{tabular}

\begin{abstract}
A B S T R A C T
Rich in natural and anthropic resources, the Romanian tourism industry offers the possibility of a total consumption by the tourists. The added value is offered to the industry by the different typologies / segments of tourists, the different tourist packages, the great variety of resources and the possibility to practice a total tourism. Consumer preferences are considered to be the most important factor in the development of the industry in an efficient and realistic way but also for making this industry internationally renouned. The methodology includes quantitative analysis, for which the data was collected using an online questionnaire, the purpose of the research being the discovery of the opinions, thoughts and feedback of the Romanian tourists on winter tourism and the infrastructure of its practice in Romania, as well as winter sports tourism.
\end{abstract}

(C) 2020 EAI. All rights reserved.

\section{Introduction}

The consumers of tourism products play an important role in the development of this industry. In contrast to other industries, the consumption of tourism products and services requires the active involvement of producers both pre-use and post-use (Dimitros B., Carlos C. 2006). Reports indicate that hundreds of millions of potential hotel customers each year consult and express their consumer preferences on various review websites. $88 \%$ of the Tripadvisor website users make choices influenced by the information found on that platform (Tripadvisor.com 2009). With the advancement of information technologies, an increasing number of travelers use the Internet to search for information about the their holiday destination (Litvin, Goldsmith and Pan, 2008). Thus, tourism is developing rapidly due to consumers, due to drastic preferences and last but not least due to the feedback they can find and give to tourism products and services (Colm Hanratty, 2015).

It is known that Romania has rich natural resources that can support winter tourism activities. Also, since 2007, Romania has access to financial resources that can be directed to the development of such winter destinations, the long-term consequence being that of the sustainability of those areas and especially the development of local mountain economies.

From the latest report done by the Swiss specialist L. Vanant (International Report on Snow and Mountain Tourism, 2020) it can be deduced that European resorts receive more visitors in general than those in North America (The Ski Guru, 2020) and Romania is not found in the top destinations in this report. The main countries recognized as inbound ski destinations are, according to this report (International Report on Snow and Mountain Tourism, 2020, p. 19): Austria, Switzerland, Italy and France. The main countries that send tourists to outbound ski destinations are the United Kingdom, Germany, the Netherlands, Belgium, Switzerland. European external markets are not growing but will be expanded to more destinations in the future. For example, British customers familiar with the Alps and Andorra now have other destinations to choose from, such as Bulgaria, Romania, Slovakia, etc. It is also foreseeable that new markets will be supplied at regional level (International Report on Snow and Mountain Tourism, 2020, p. 19).

According to the same report (International Report on Snow and Mountain Tourism, 2020, p.128) the Carpathian Mountains are the second largest mountain range in Europe but Romania is still a winter vacation quite unknown and undiscovered destination. It has 44 ski resorts with about 150 ski lifts, of which $20 \%$ have been installed or renewed in the last 15 years. It is an attractive destination for foreign visitors, as the prices are relatively low compared to most of Europe, and some ski slopes are lit for night skiing. However, overpasses are not considered cheap due to limited infrastructure and poor care. It is estimated that ski resorts in Romania will attract approximately 1.2 million visits to skiers per year.

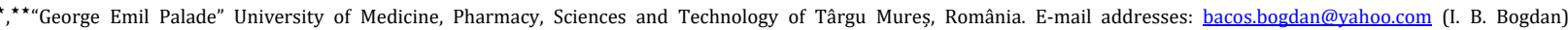
manuela.gabor@umfst.ro (M. R. Gabor) 
The purpose of this paper is to analyze the preferences of Romanian consumers regarding winter tourism, their availability and how to spend their winter vacation, the average expenses in a winter vacation and the quality of tourist services offered by winter tourism providers in Romania.

\section{Literature review}

Sports tourism is defined by Standeven and De Knop (1999) as "all forms of active and passive involvement in sports activity, occasionally or organized participation for business / commercial reasons, which require travel away from home" (p.12). Although explained simply and rationally, Weed (2008) questioned the value of such a definition because it suggested that it does not provide a thorough and descriptive understanding of what sports tourism is. In this context, researchers had to separate sports tourism (seen as an industry) from sports tourism (the pawn of the industry).

Gibson (1998) classifies sports tourism into 2 dimensions: active sports tourism (non-professional) and event sports tourism (professional). The people practicing active sports travel to meet their hobby needs, while the event sports tourists travel to watch or participate in a sporting activity. Robinson and Gammon (2004) considered that their original paper (1997) had no theoretical basis and further developed their concepts of tourism in secondary consolidation categories. This included a "professional" and "hobby" framework for sports tourism.

A professional sports tourist is one who travels to participate in or watch a sporting event. The competitive component is the "professional" aspect. Therefore, the "hobby" aspect is when someone participates in sports, but pursues reasons for relaxation/recreation and not competitive reasons.

Winter sports tourists make up one of the largest activity-based market segments in most countries, both European and overseas. This study contributes to the limited research and discovery of tourists' motivation in practicing winter sports tourism. The work that has been done on motivation in choosing leisure tourism and ski destination is largely descriptive (Richards, 1996; Ryan \& Glendon, 1998; Won \& Hwang, 2009) with only a few exceptions (Klenosky, Gengler \& Mulvey, 1993)). Such a descriptive work has aroused the interest of other renowned researchers in sports tourism (Gibson, 2004; Weed, 2008) by asking the question: "What do we really know about the motivation of tourists practicing winter sports?".

\section{Winter sports tourism in Romania}

In Romania, there are currently 211 kilometers of slopes served by approximately 150 cable transport installations. The list of the best ski resorts in Romania includes Straja and Sinaia ski resorts with 3 stars out of 5 stars according to the 2020 Report made by the Austrian website Skiresorts.info. Thus, Straja is also the largest ski resort offering the longest slopes (about $20 \mathrm{~km}$ ).

The highest ski resorts in Romania stretch to an altitude of 2,208 meters (Balea Lac). A quantitative analysis of the main winter tourist destinations, namely the number of kilometers of practicable areas of winter sports, the total number of cable transport facilities and accommodation capacity in each county can be found in table no. 1 and the number of cable transport facilities.

Table 1. Accommodation capacity, number of resorts, total number of $\mathrm{km}$ and number of cable transport installations by counties

\begin{tabular}{|c|c|c|c|c|}
\hline County & $\begin{array}{l}\text { No. of } \\
\text { resorts }\end{array}$ & $\begin{array}{c}\text { Total no. of } \\
\text { practicable km }\end{array}$ & $\begin{array}{c}\text { Total no. of cableway } \\
\text { installations }\end{array}$ & $\begin{array}{c}\text { Accommodation } \\
\text { capacity (2017) }\end{array}$ \\
\hline Alba & 1 & 12.3 & 3 & 191 \\
\hline Bacău & 1 & 1.4 & 1 & 147 \\
\hline Bihor & 3 & 4.2 & 5 & 216 \\
\hline Bistrița-Năsăud & 2 & 2.5 & 2 & 87 \\
\hline Brașov & 3 & 24.1 & 14 & 955 \\
\hline Caraș-Severin & 3 & 14 & 8 & 241 \\
\hline Cluj & 4 & 6.8 & 6 & 283 \\
\hline Covasna & 1 & 0.8 & 2 & 104 \\
\hline Gorj & 1 & 3.4 & 6 & 102 \\
\hline Harghita & 9 & 22.7 & 19 & 409 \\
\hline Hunedoara & 2 & 27.7 & 20 & 217 \\
\hline Iasi & 1 & 0.5 & 1 & 85 \\
\hline Maramures & 7 & 20.8 & 14 & 277 \\
\hline Mures & 1 & 1.5 & 3 & 362 \\
\hline Neamt & 1 & 1.2 & 3 & 267 \\
\hline
\end{tabular}




\begin{tabular}{|c|c|c|c|c|}
\hline County & $\begin{array}{c}\text { No. of } \\
\text { resorts }\end{array}$ & $\begin{array}{c}\text { Total no. of } \\
\text { practicable km }\end{array}$ & $\begin{array}{c}\text { Total no. of cableway } \\
\text { installations }\end{array}$ & $\begin{array}{c}\text { Accommodation } \\
\text { capacity (2017) }\end{array}$ \\
\hline Prahova & 3 & 28.8 & 17 & 347 \\
\hline Sibiu & 3 & 18.2 & 8 & 338 \\
\hline Suceava & 3 & 11.2 & 7 & 441 \\
\hline Valcea & 1 & 6.1 & 5 & 260 \\
\hline
\end{tabular}

Source: Made by the author based on the information from https://www.skiresort.info/ski-resorts/romania/

As a tourist attraction for foreign visitors, Romania stands out for its relatively low prices compared to most of Europe. However, the price of subscriptions is not considered really cheap due to the limited and weak infrastructure. It is estimated that the resorts in the Carpathian Mountains attract about 1.2 million skiers annually according to Laurent Vanat in the 2020 Snow \& Mountain Tourism Report. According to the chart no. 1 we can see that the number of winter sports enthusiasts is about 588,000 people, and the 141 cable installations are not enough for a favorable practice of winter sports in Romania.

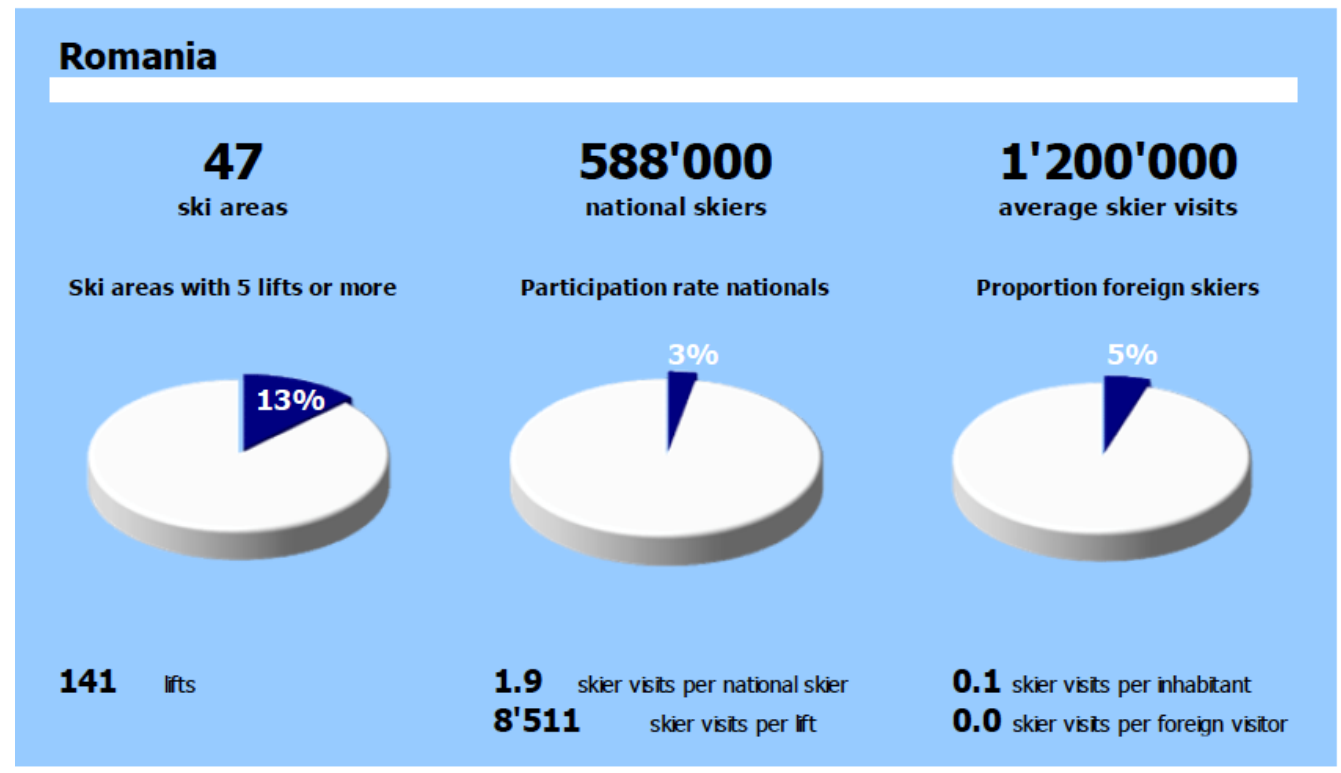

Figure 1. Graph on the situation of winter destinations in Romania 2020

Source: Made by the author based on the information from 2020's Report on Snow \& Mountain Tourism

\section{The preferences of Romanian consumers}

Between September 2019 and February 2020, a questionnaire was applied, addressed especially to Romanian tourists, in order to obtain information on the preferences and options of consumers of winter sports in Romania. The questionnaire was applied to a number of 102 respondents. The simple questions with closed answers were correlated especially to the quality of services, consumer preferences, the pricequality ratio and last but not least the general feedback following the practice of winter sports in Romania.

From the first questions we can deduce the intention of Romanian tourists to practice winter sports in Romania. Thus, according to figure no. 2 on "How to spend a holiday among Romanian tourists" we see a number of 60 people prefer to spend their winter vacation practicing winter sports. 


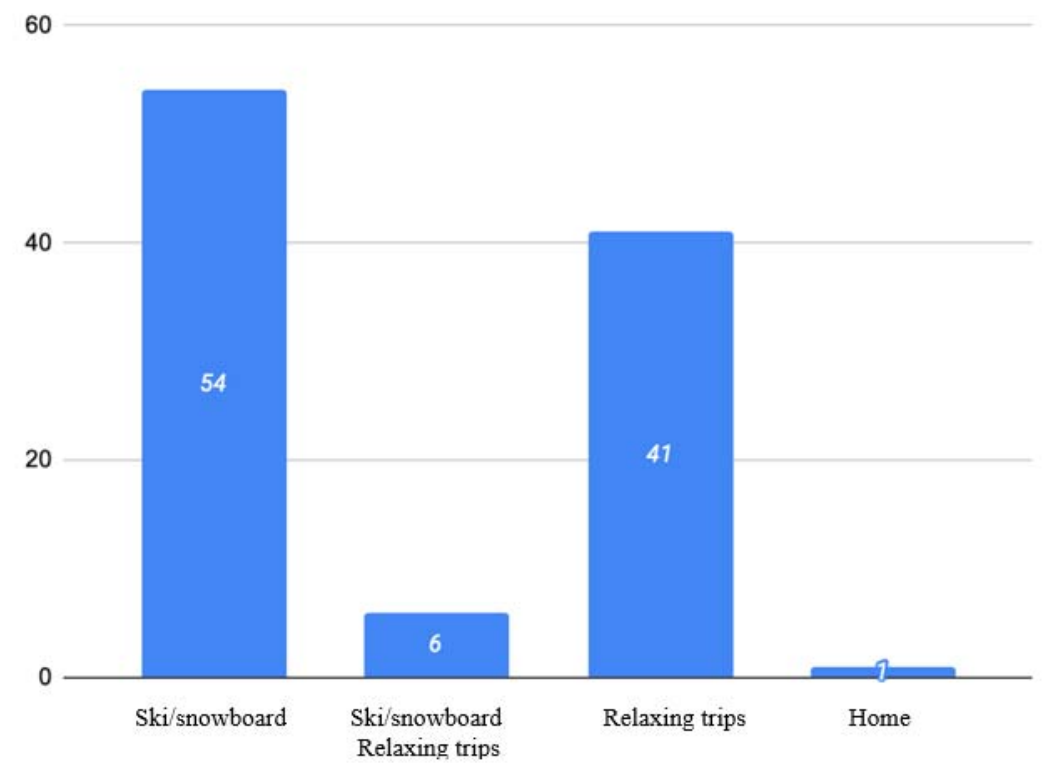

Figure 2. The way of spending the holiday among Romanian tourists Source: Made by the author based on the applied questionnaire

On average, Romanian tourists choose to travel, or spend their winter vacation, every year $(71.6 \%)$ according to figure no. 3 on "the frequency of winter holidays of Romanian tourists". Looking at the same graph, one can notice that only 14 people are traveling to winter destinations more than 2 times a year $(13.7 \%)$.

According to the study conducted by MKOR Consulting in 2018, most Romanians usually go once a year $(31 \%)$ or twice a year (36\%). A smaller percentage, almost a quarter of respondents - $23 \%$ - go on vacation 3-4 times a year, while $7 \%$ go on vacation more than 5 times a year. A percentage of $4 \%$ of Romanians never go on vacation.

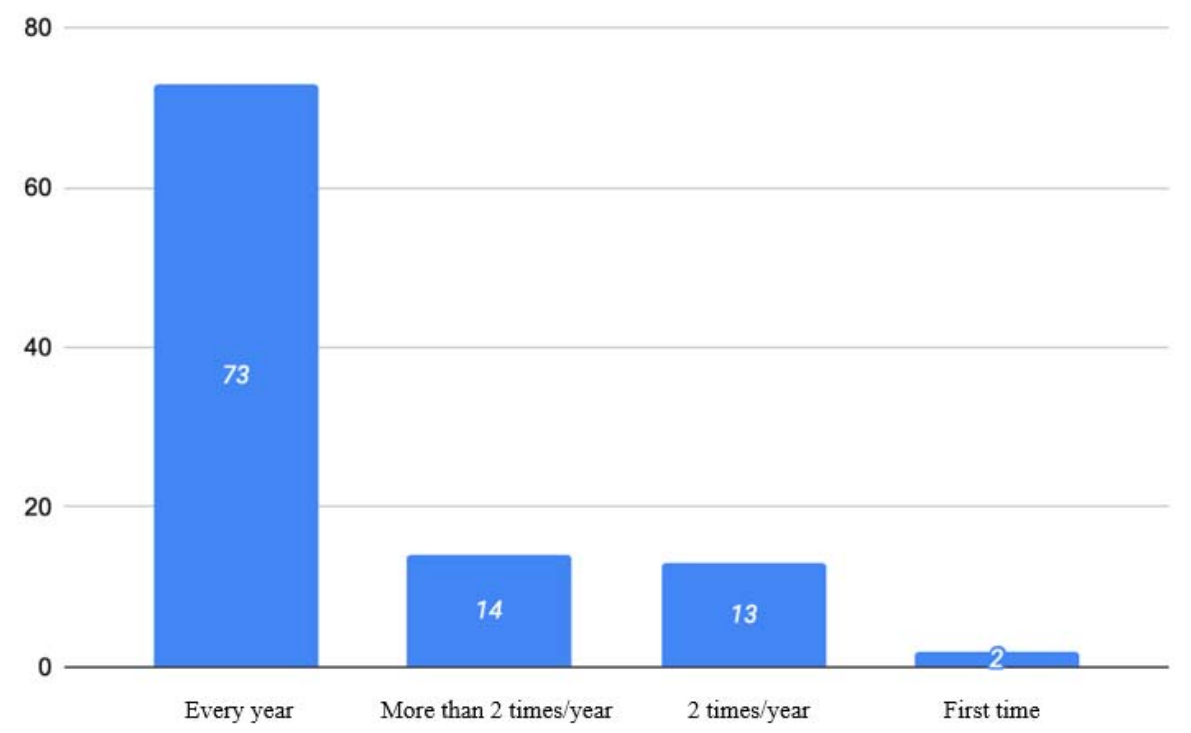

Figure 3. Frequency of winter holidays of Romanian tourists

Source: Made by the author based on the applied questionnaire

Another important factor in conducting the case study was the classification of respondents according to the experience of practicing winter sports. Thus, according to figure no. 4 regarding the "level of experience of winter sports practitioners in Romania" we find a number of 49 respondents as beginners, 42 intermediate people and only 11 advanced people.

The winter resorts in Romania are especially sought after by beginners, because over $50 \%$ of the slopes are blue and green, but there are also red slopes, with medium difficulty, in a proportion of approximately $40 \%$. 


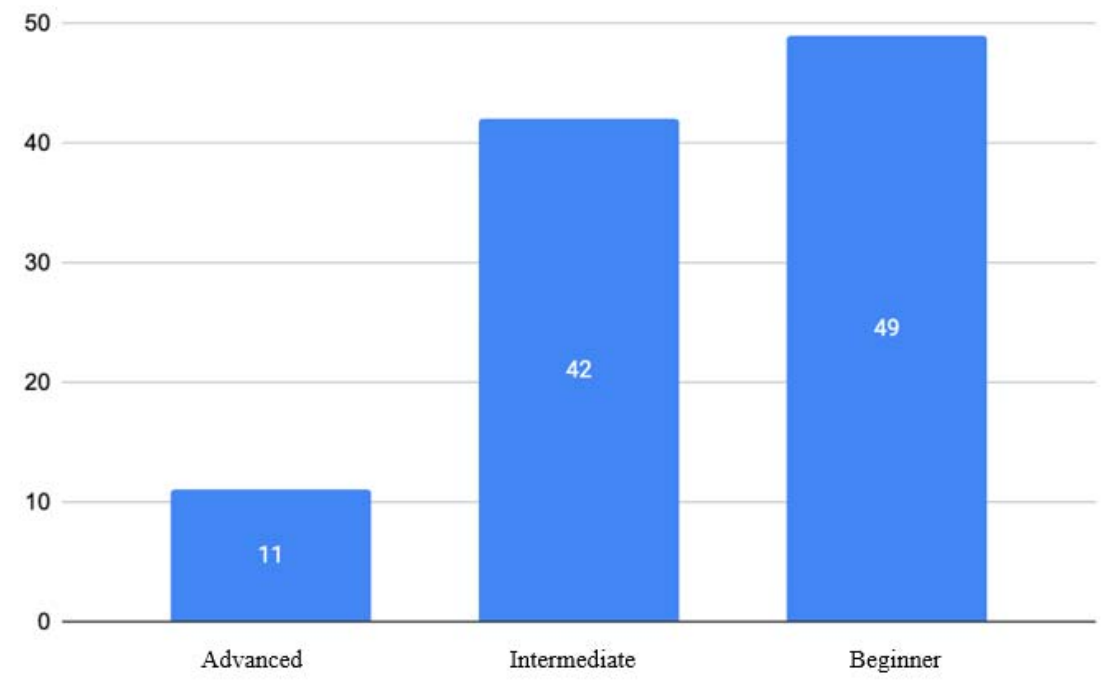

Figure 4. The level of experience of winter sports practitioners in Romania Source: Made by the author based on the applied questionnaire

As we presented in the previous part of the research, in Romania there are currently 211 kilometers of slopes served by approximately 150 cable transport installations. According to figure no. 5 on "Distance in $\mathrm{km}$ traveled by respondents in a winter vacation", we find a number of 47 people and a share of $46.07 \%$ of respondents who say that the average distance traveled by practicing winter sports is in the category of 10 $50 \mathrm{~km}, 33$ people (34.3\%) completed between 50-100 km and 11 people (12.8\%) between 100-150. After some detailed studies, I found that Romanians travel not only to ski in mountain resorts, but also to relax, to enjoy the wellness \& spa services and to spend time with their loved ones.

Another important factor is given by the transport capacity of the seats and gondolas, because the waiting time to make a climb is quite long in the Romanian resorts, sometimes reaching even 30 minutes, unlike Austria, where the maximum waiting time does not exceed 5 minutes.

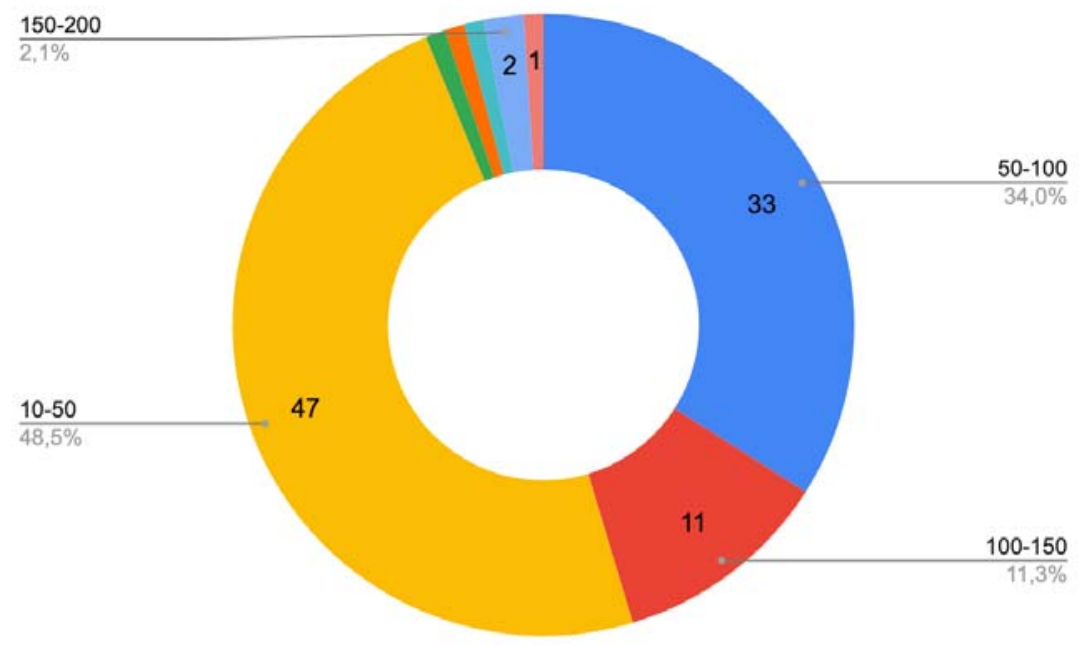

Figure 5. Distance in $\mathrm{km}$ traveled by respondents on a winter vacation Source: Made by the author based on the applied questionnaire 

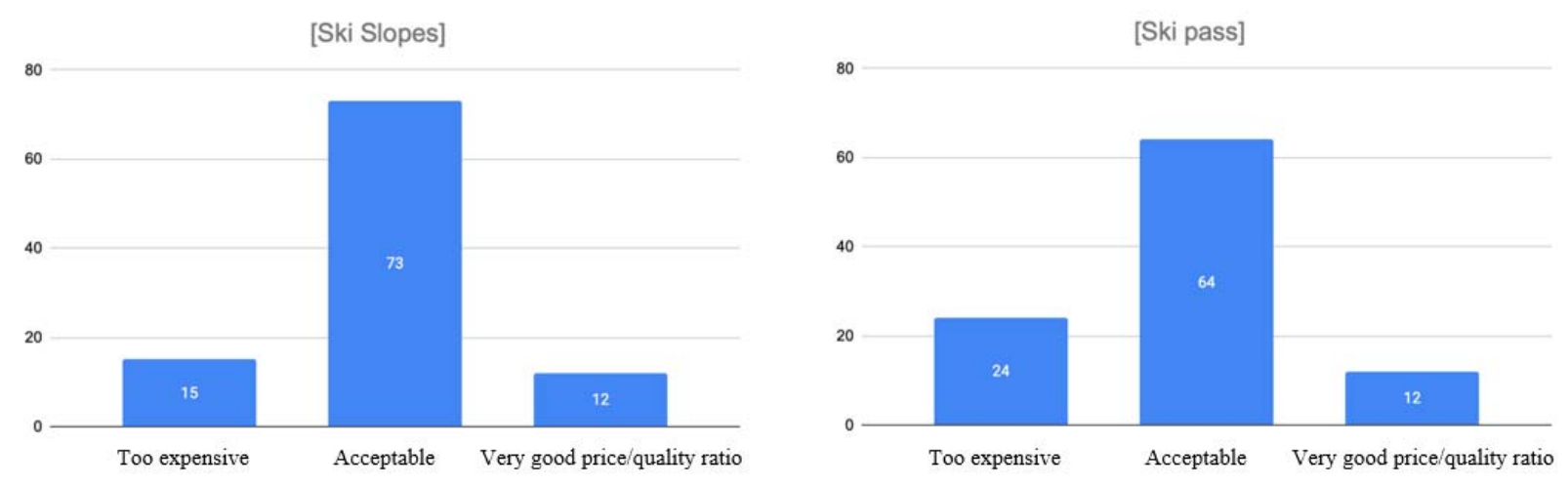

Figure 6. Price to quality ratio

Source: Made by the author based on the applied questionnaire

Knowing the price that tourists pay for services received in winter destinations in Romania, and to analyse in detail the quality of services, the goal was to find out how satisfied tourists are with the services they pay, if they would prefer to pay less for the same services, or prefer to pay more to receive increased quality.

According to figure no. 6 regarding the price to quality ratio, we notice that most of the interviewees are of the opinion that the ratio between the price offered and the quality received is acceptable. On average, the price of a daily subscription according to Ski-in-Romania is between 100-180 lei for adults and between 70-150 for children.

An important factor in influencing the decision of consumers, remains the quality of services offered by service providers in mountain resorts, here we remind: the condition of the slopes, accommodation, food, staff friendliness, services offered in wellness \& spa, bars, treatment, etc.

According to the applied questionnaire, the respondents found that among those mentioned above, the condition of the slopes is the most important factor that can negatively or positively influence the quality of services. According to figure 7. regarding the "Main factors of influence in the choice of winter destinations" it is observed that 73 respondents consider as very important and important the condition of the slopes when choosing a holiday package. Another important factor is the friendliness of the staff in winter destinations. Regarding this indicator, 75 people consider it very important and important for the employees of the tourist resorts to be kind and communicative.
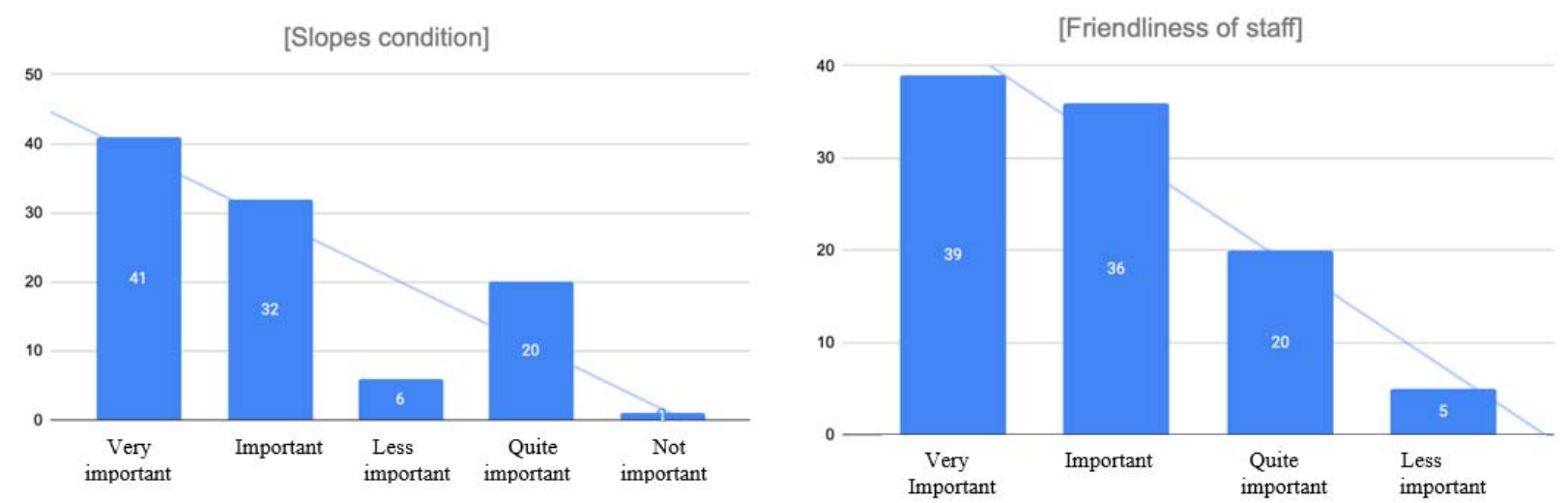

Figure 7. Factors influencing the choice of winter destinations

Source: Made by the author based on the applied questionnaire

Regarding the interest of tourists in the condition of the slopes as being the main factor in influencing the decision, on a scale of 1-10, respondents had the free choice to catalog the condition of the slopes in Romania. Thus, according to figure no. 8 regarding the "state of the slopes in Romania" it was chosen as being of grade 7 in proportion of 33\%, followed by grade 6 with $20 \%$ and 8 with $19 \%$. 


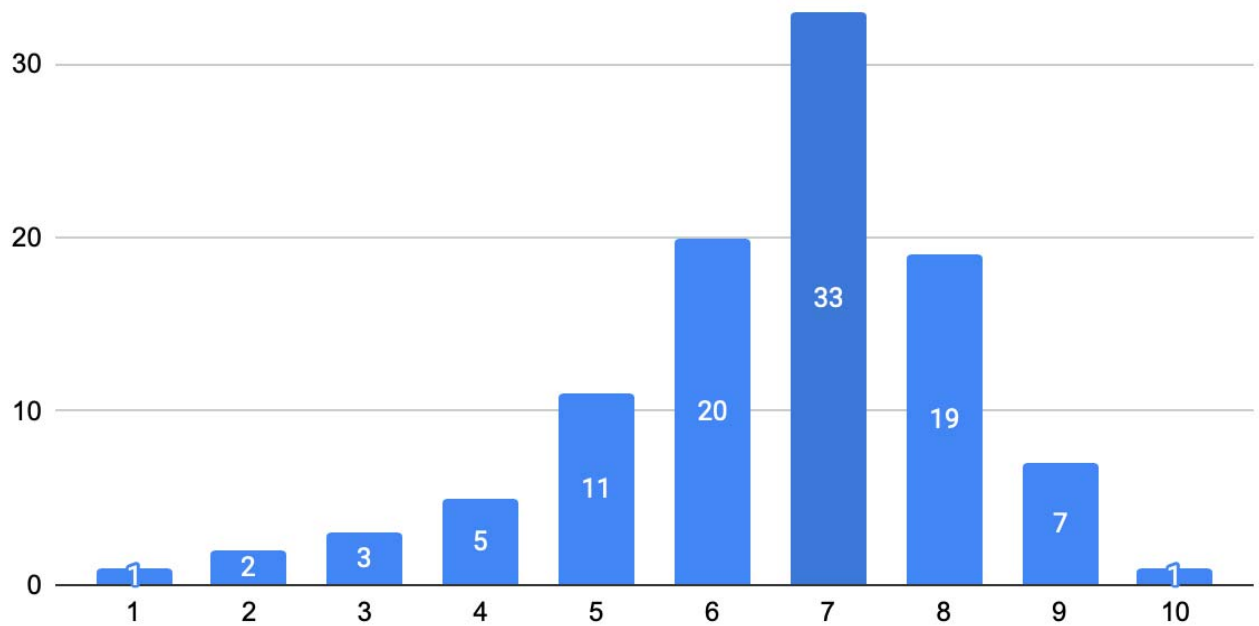

Figure 8. State of the slopes in Romania (1-10)

Source: Made by the author based on the applied questionnaire

In order to highlight the future desire to return to winter resorts, and the need for feedback, we asked the respondents the following question: "Do you want to schedule your next winter vacation in Romania as well?". According to figure no. 9 regarding "The desire to return to the winter resorts in Romania" 48 respondents answered "YES" and 46 answered "MAYBE".

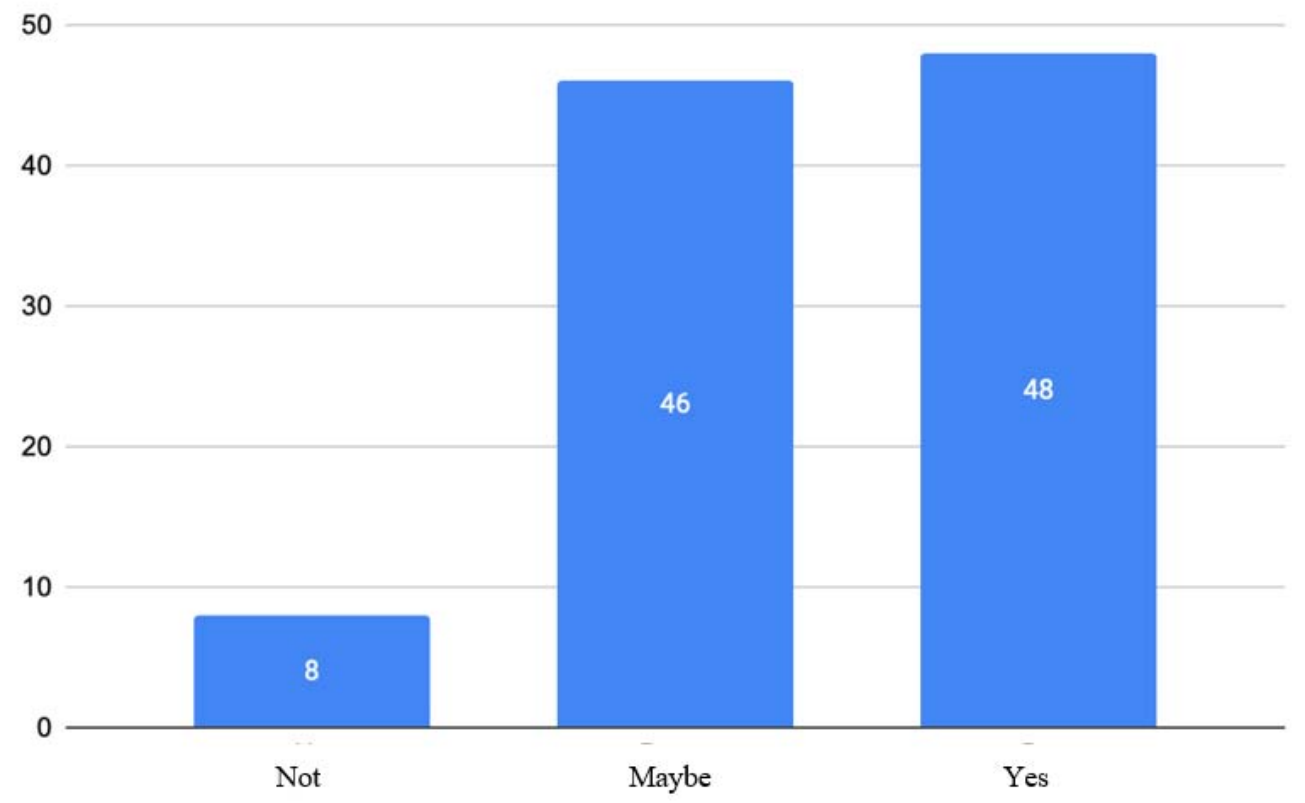

Figure 9. The desire to return to the winter resorts in Romania

Source: Made by the author based on the applied questionnaire

\section{Conclusions}

Mountain tourism and especially the consequences of mountain tourism through practicing winter sports can be found mostly in the Carpathians, in the counties and cities/mountain towns in Romania.

By developing winter tourist resorts, the main aim is to develop the infrastructure and the material base, but last but not least, to satisfy the needs of consumers.

Consumers of tourist services have an important role in increasing the quality of tourist products in winter resorts. Thus, their motivation to actively participate and consume the services provided must be taken into account by both authorities and private industry providers.

The present quantitative research has shown that the condition of the ski slopes and the friendliness of the staff are important in the decision to choose the destination. According to this study, respondents 
appreciate the quality of services through the perspective of these indicators and consider it important that there is an acceptable price to quality ratio for the services offered in Romania.

Finally, although there is a great need for innovation and investment to increase both the number of kilometres usable in winter resorts and the number of cable facilities, Romanian tourists enjoy the winter vacation offers in Romania annually. Future research will include a comparative study Romania-Austria on winter tourism and implicitly the practice of winter sports (more precisely skiing) in these two countries.

\section{References}

1. Bacoș I. (2018). “Studiu comparativ privind sporturile de iarnă Austria-România”, Bachelor thesis ,Universitaty of Petru Maior Târgu Mureș

2. Bacoș I. (2018) .Studiu de caz privind destinațile de iarnă Austria-România" - Paper presented and awarded on 07.05.2018 with the first prize at the Communication Session of student scientific circles, section "Studies and research in the field of business and services" Petru Maior University, Târgu Mures,

3. Buhalis D., Costa C. (2006) .Tourism Busines frontiers. Consumers, products and industry. Turism futures, pp. 5-11.

4. Dediu L. (2016) - Users' reviews on tourism sites: their influence on the potential tourists valabil online pe https://www.cactus-journalof-tourism.ase.ro/Pdf/vol13/Dediu-stud.pdf

5. Dimitros B., Carlos C. (2006) - Tourism management dynamics, Elseivier, pp. 10-15

6. Finn B. (2012) - "Exploring Ski Tourist Motivations for Active Sport Travel" Electronic Theses and Dissertations, pg. 1-8

7. Gammon S., Robinson T., (2003) - Sport and Tourism: A ConceptualFramework, Journal of Sport \& Tourism, pg 82-94

8. Gibson H., (1998) - Sport Tourism: A Critical Analysis of Research, The University of Florida, Center for Tourism Research andDevelopment, Department of Recreation, Parks and Tourism, 45-76

9. Gibson H., (2006) - Sport Tourism: Concepts and Theories. An Introduction, Sport in society, JOUR, pg 8-22

10. Hanratty C. (2015) - 7 reasons customer reviews are important for your tourism website valabil online pe https://www.trekksoft.com/en/blog/why-customer-reviews-are-important

11. Holden A., (2002) - Environment and Tourism. Economic Geography, pg 16-20

12. Klenosky D., Gengler C., Mulvey M., (1993) - Understanding the Factors Influencing Ski Destination Choice: A Means-End Analytic Approach. Journal of Leisure Research. pg. 22-40

13. Litvin S., Goldsmith R., si Pan B., (2008) - Electronic Word-of-Mouth in Hospitality and Tourism Management

14. Manfredo M., Driver B., Tarrant M., (1996) - Measuring Leisure Motivation: A Meta-Analysis of the Recreation Experience Preference Scales. Journal of Leisure Research

15. Mkor (2018) - Studiul piața de turism -vacanța de iarnă 2018, Studii, Cercetări și Ghiduri marca MKOR - valabil online pe: https://mkor.ro/studii-proprii/

16. Neacsu M., Neacșu N., Baron P, Glavan V (2011) - Geografia si economia turismului, Pro Universitaria ,pg.155-176

17. Oliver K. (2020) Ski resorts Romania valabil online pe: https://www.skiresort.info/ski-resorts/romania/

18. Price.M, F., Jansky, L. Iatsenia, A. (2004) Key Issues for Mountain Areas, United Nations University Press, New York,

19. Richards G., (1996) - Cultural Tourism in Europe, CAB International, Wallingford, Uk, pg. 12-18

20. Ryan C., Glendon I., (1998) - Application of leisure motivation scale to tourism, Annals of Tourism Research, Volume 25, Issue 1,

21. Saji J. (2020) What does consumer preference actually mean? valabil online pe https://medium.com/@jessicatreesasaji/what-doesconsumer-preference-actually-mean-5ae6a3c93055

22. Standeven J., Knop P. (1999) - Sport tourism, Human kinetics, pg. 15-20

23. Vanat, L. (2020). 2020 International Report on Snow \& Mountain Tourism Overview of the key industry figures for ski resorts, Geneva, Switzerland, valabil pe www.vanat.ch/tarif-WR-data-2020.pdf

24. Weed M., (2008) - Olympic tourism, Oxford: Elsevier Ltd 236, pg 60-72 